\title{
A COST-EFFICIENT METHOd TO REMOTELY MONITOR STREAMFLOW IN SMALL-SCALE WATERSHEDS
}

\author{
Abbie LaNell Lasater ${ }^{1, *}$, Meagan O’Hare ${ }^{1}$, Brad J. Austin ${ }^{1}$, Erin Scott ${ }^{2}$, Brian E. Haggard ${ }^{1}$ \\ ${ }^{1}$ Department of Biological and Agricultural Engineering, University of Arkansas, Fayetteville, Arkansas, USA. \\ 2 Ozarks Water Watch, Rogers, Arkansas, USA. \\ *Correspondence: alasater@gbmcassoc.com
}

\section{Highlights}

- A HOBO water level logger was deployed to obtain a continuous stage record across sites.

- SonTek-IQ acoustic Doppler instruments were deployed to measure discharge during high-flow events.

- Rating curves were developed using linear regression, LOESS regression, and Manning's equation.

- The proposed method provides an opportunity to collect continuous flow records across multiple, small-scale watersheds.

\begin{abstract}
Discharge monitoring stations are often costly and difficult to install, operate, and maintain, especially in small streams. The purpose of this study was to evaluate a low-cost method for remotely monitoring streamflow in small-scale watersheds to provide continuous discharge measurements across multiple sites and flow conditions. Within the Upper Poteau River Watershed (UPRW) in Arkansas, 12 sites were selected at bridge crossings near the outflow of HUC-12 or HUC-14 subwatersheds. A HOBO water level logger was deployed at each site to obtain continuous stage records, and HOBO barometric pressure transducers were installed within $16 \mathrm{~km}$ of each sample site to account for fluctuations in atmospheric pressure. SonTek-IQ acoustic Doppler instruments were deployed to measure discharge during high-flow events, and roving discharge monitoring stations were installed at each site to allow easy rotation of the SonTek-IQ instruments among sites between flood events. Once the roving discharge monitoring stations were installed at each site, one or more SonTek-IQ instruments could be rotated among sites to capture high-flow discharge measurements; therefore, a SonTek-IQ instrument was not required for every site of interest. The high-flow data captured during SonTek-IQ deployment, and baseflow discharge measurements collected on a monthly basis, were used to develop rating curves with a combination of simple linear regression, LOESS regression, and Manning's equation. The rating curves well represented the measured flows, with Nash-Sutcliffe efficiencies ranging between 0.87 and 0.98. This method provides an opportunity to collect continuous records offlow across multiple, remote, small-scale watersheds, and in conjunction with constituent concentrations and load estimations, can be used to calibrate and validate watershed models.
\end{abstract}

Keywords. Rating curves, Small-scale watersheds, Streamflow monitoring.

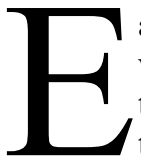

arth's freshwater resources are essential for human well-being, ecosystem services, and economic activity. While only representing a small fraction of the global water supply, freshwater provides sources for drinking water and irrigation, opportunities for sports and recreation, and habitat for more than 100,000 plant and animal species (Aylward et al., 2005; Dudgeon et al., 2006). Due to increasing population and land use changes, human activity has been a major influence on freshwater ecosystems (Sala et al., 2000; Dudgeon et al., 2006). When combined with climate change impacts such as increasing temperatures and variations in hydrologic cycles,

\footnotetext{
(c) (1) $\Theta$ The authors have paid for open access for this article. This C. ${ }_{\mathrm{BY}} \mathrm{NC}_{\mathrm{ND}}$ work is licensed under a Creative Commons AttributionNonCommercial-NoDerivatives 4.0 International License https://creative commons.org/licenses/by-nc-nd/4.0/

Submitted for review on 28 June 2021 as manuscript number NRES 14730; approved for publication as a Research Article by the Natural Resources \& Environmental Systems Community of ASABE on 19 January 2022.
}

large amounts of stress are applied to freshwater quantity and quality (Jiménez Cisneros et al., 2014). Therefore, efforts to monitor freshwater ecosystems are increasingly important for sustainable water management.

Regular, long-term streamflow data can be used to understand changes in hydrology and trends in natural disturbances (e.g., flooding and drought) in freshwater ecosystems (Dai and Trenberth, 2002; Erwin and Hamilton, 2005; Haritashya et al., 2006; Peterson et al., 2013; Chen et al., 2014). This information can help to develop effective policy, allocate water supplies, and assess the effectiveness of management practices. For example, the Ecological Limits of Hydrologic Alteration (ELOHA) framework was developed by synthesizing decades of global streamflow data (Poff et al., 2010) and is used to determine empirical relationships between flow alterations and ecological responses across streams. This extensive streamflow database has been applied in numerous case studies to implement policy, manage flows, and achieve river condition goals (Martin et al., 2015; Solans and García de Jalón, 2016; Zhang et al., 2016; Stein et al., 2017). 
When nutrient and sediment concentrations are monitored in conjunction with streamflow, water quality trends can be evaluated while adjusting for discharge (Hirsch et al., 1982; Helsel and Hirsch, 1991), and constituent loads can be estimated (Cohn et al., 1989; Migliaccio et al., 2010). Constituent loads and streamflow measurements are important for calibrating and validating watershed and reservoir models (Silberstein, 2006), which can be used to predict various water resource scenarios under the impact of environmental and management changes, as well as develop total maximum daily loads (TMDLs). Watershed models help to establish watershed management plans and pollution prevention strategies (Erwin and Hamilton, 2005), as well as identify priority areas of concern within a watershed (e.g., Tripathi et al., 2003; Pai et al., 2011; Welde, 2016).

Discharge monitoring stations are often costly and difficult to install, operate, and maintain, especially in small streams. Discharge estimations are typically conducted using the velocity-area method (i.e., velocity across the stream multiplied by the cross-sectional area), where velocity is measured with various techniques including current meters, dilution gauging, or acoustic Doppler current profilers (Dobriyal et al., 2017). However, velocity measurements are typically instantaneous and must be collected manually in the stream, which can be dangerous under some flow conditions or difficult in numerous, remote streams. Additionally, it can be difficult to ensure that velocity measurements are representative of the entire flow profile of a given stream. Discharge is sometimes estimated using hydrologic control structures (e.g., weirs or flumes), and flow is calculated based on the changes in flow depth (Turnipseed and Sauer, 2010). However, hydrologic control structures are impractical for monitoring numerous, small-scale streams across a watershed.

Due to the costs and feasibility associated with discharge estimations, monitoring data for small-scale streams are often limited within the watershed of interest. Therefore, watershed models are often used to predict constituent concentrations and flow conditions for small-scale streams, but data to validate these outputs are typically unavailable (Pai et al., 2011; Welde, 2016). The purpose of this study was to introduce a cost-efficient method for remotely monitoring streamflow in small-scale watersheds.

\section{Materials ANd Methods}

\section{STUDY SITE DESCRIPTION}

The Upper Poteau River Watershed (UPRW) (HUC 11110105 ) occupies an area of $1,400 \mathrm{~km}^{2}$ in Arkansas (fig. 1). In 2001, land use in the UPRW was $60 \%$ forested, $26 \%$ agriculture, $6 \%$ urban, $4 \%$ grassland, and $1 \%$ open water (USGS, 2001). In 2016, the forested area had increased to $65 \%$, the agriculture area had decreased to $22 \%$, while the urban, grassland, and open water areas were unchanged (USGS, 2016). The headwaters of the Poteau River begin near Waldron, Arkansas, and flow west into Oklahoma, near Loving, Oklahoma. The two main tributaries to the Poteau

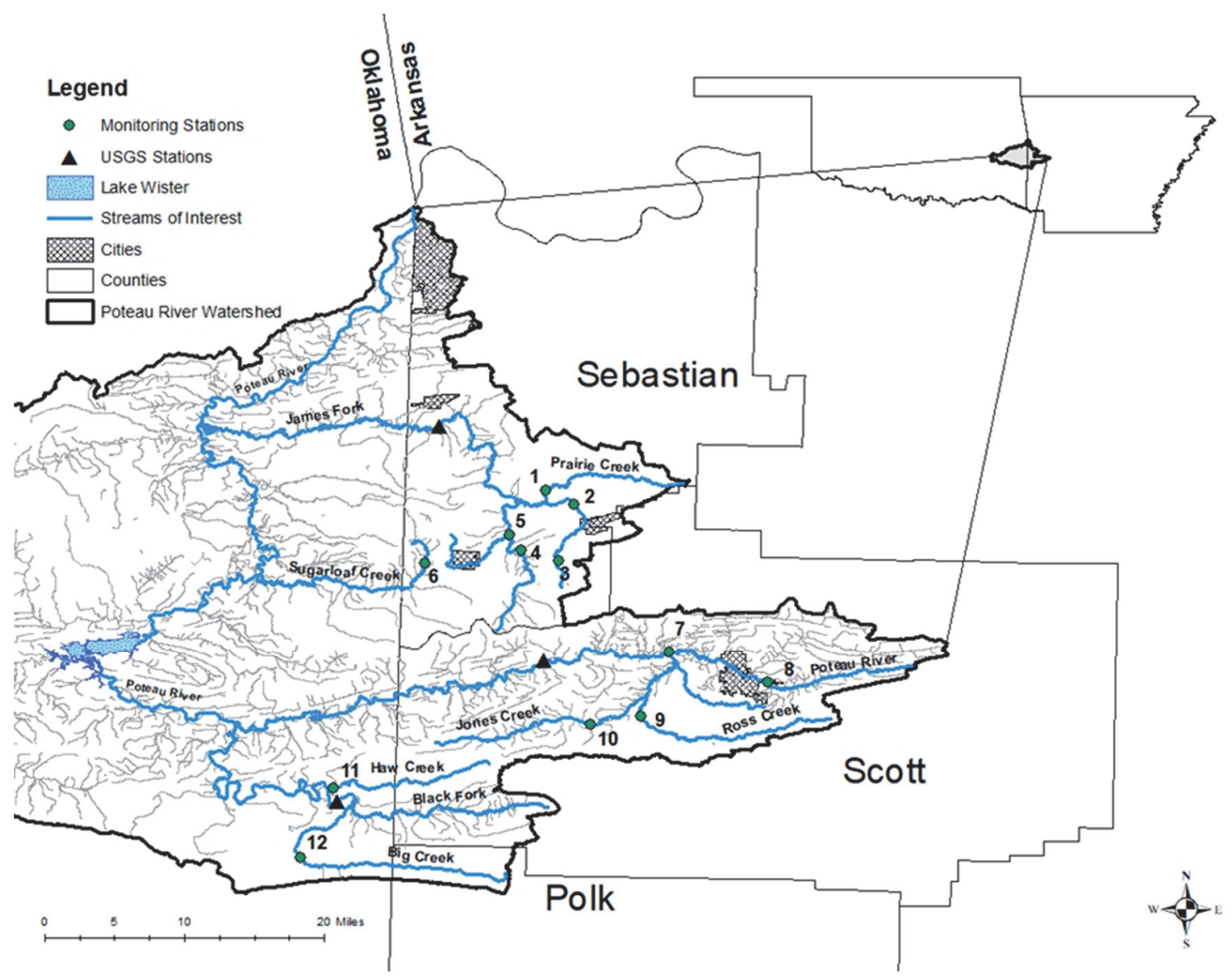

Figure 1. Monitoring sites in the Upper Poteau River Watershed in Arkansas. Site numbers correspond to the site IDs in table 1. 
River within the UPRW in Arkansas are the Black Fork and the James Fork.

The UPRW has been listed as a priority watershed in the Arkansas Nonpoint-Source Pollution Plan since 1998 and has been a focus of trans-boundary water quality issues for the last several decades (ANRC, 2018). In 2017, the UPRW contained more than 350 poultry farms and produced nearly 100 million birds (USDA, 2017). Portions of the Poteau River are listed on the Arkansas 303(d) list for dissolved oxygen, turbidity, chlorides, sulfates, and total dissolved solids (ADEQ, 2018). A TMDL was developed in 2006 for the Poteau River, which concluded that a $35 \%$ reduction in total phosphorus (TP) from nonpoint sources was necessary for water quality protection (USEPA, 2006).

For this study, 12 sites were selected at bridge crossings near the outflows of HUC-12 or HUC-14 subwatersheds within the UPRW (fig. 1 and table 1) to represent a range of land use and baseflow water quality conditions. Land use ranged from $23 \%$ to $92 \%$ forested, from $1 \%$ to $8 \%$ urban, and from $0 \%$ to $61 \%$ agriculture (mostly pasture). Barren land represented less than $1 \%$ of the catchment area for all watersheds, and the remainder of the watershed areas were open water, shrubs, and grasslands (USGS, 2016). The catchment area ranged from 7 to $193 \mathrm{~km}^{2}$ across all sites (table 1).

\section{Data Collection}

HOBO water level loggers (i.e., pressure transducers; Onset Computer Corp., Bourne, Mass.) were deployed in December 2017 to obtain continuous stage records. At each site, a water level logger was installed in a polyvinyl chloride (PVC) pipe attached to the downstream side of a bridge pier (fig. 2a). While installation on the downstream side produced stage readings that were artificially lower than the actual stage, this error was acceptable because of the benefits of protection from debris in the streamflow. A HOBO barometric pressure sensor (pressure transducer) was attached to a tree outside the floodplain within $16 \mathrm{~km}$ of each site to account for atmospheric pressure fluctuations (fig. 2b). The HOBO water level loggers and barometric pressure sensors were maintained according to manufacturer guidance
(Onset, 2018) and recorded measurements at 15 min intervals that were downloaded on a monthly basis.

SonTek-IQ acoustic Doppler instruments (SonTek/Xylem Inc., San Diego, Cal.) were deployed to measure discharge during high-flow events. These SonTek-IQ instruments measure the velocity of water using the Doppler shift and internally calculate discharge once calibrated to the stream channel geometry. Roving discharge monitoring stations were installed at each site to allow easy rotation of the SonTek-IQ instruments among sites between flood events. The roving discharge monitoring stations included a concrete base staked into the streambed, a container to store the battery and wiring (i.e., a waterproof ammo box), and PVC pipe from the concrete base up the streambank to the battery container (figs. $2 \mathrm{c}$ to $2 \mathrm{e}$ ). The battery container was attached to a tree outside of the floodplain (fig. 2e).

Once the roving discharge monitoring stations were installed at each site, one or more SonTek-IQ instruments could be rotated among sites to capture high-flow discharge measurements; therefore, a SonTek-IQ instrument was not required for every site of interest. Rating curves were developed for all sites using the high-flow data captured during SonTek-IQ deployment. Baseflow discharge measurements, collected on a monthly basis using velocity-area methods, were also used because SonTek-IQ flow measurements are not reliable when water depths are less than $0.45 \mathrm{~m}$ (SonTek, 2017).

\section{RATING CURVE DEVElopMENT}

Selected data from the SonTek-IQ instruments (peak flows, $75 \%$ of peak flows, and $50 \%$ of peak flows on the rising and falling limbs) were combined with baseflow discharge measurements (using velocity-area methods) and the associated instantaneous stage to develop rating curves. Rating curves were developed using a three-step process:

- $\quad$ First, nonparametric LOESS regression was used to fit the range of the measured flow and stage data with a sampling proportion of 0.5 .

- Second, below the range of the measured flow data, two-point regression was applied to estimate low flows.

Table 1. Monitoring site IDs (corresponding to fig. 1), names, locations, watershed areas, and land uses in the Upper Poteau River watershed.

\begin{tabular}{|c|c|c|c|c|c|c|c|}
\hline Site ID & Site Name & $\begin{array}{l}\text { Latitude } \\
\text { (north) }\end{array}$ & $\begin{array}{c}\text { Longitude } \\
\text { (west) }\end{array}$ & $\begin{array}{l}\text { Watershed } \\
\text { Area }\left(\mathrm{km}^{2}\right)\end{array}$ & $\begin{array}{c}\text { Forested } \\
(\%)^{[a]}\end{array}$ & $\begin{array}{l}\text { Urban } \\
(\%)^{[b]}\end{array}$ & $\begin{array}{c}\text { Agriculture } \\
(\%)^{[\mathrm{c}]}\end{array}$ \\
\hline \multicolumn{8}{|c|}{ James Fork Watershed (HUC 1111010508) } \\
\hline 1 & Prairie Creek & 3505.709 & 9417.776 & 70 & 23.0 & 5.1 & 61.4 \\
\hline 2 & Lower Cherokee Creek & 3504.839 & 9416.013 & 80 & 45.1 & 6.0 & 46.4 \\
\hline 3 & Headwaters Cherokee Creek & 3501.379 & 9416.985 & 14 & 84.5 & 1.1 & 9.4 \\
\hline 4 & Headwaters James Fork & 3501.984 & 9419.315 & 39 & 84.7 & 1.2 & 8.9 \\
\hline 5 & Lower James Fork & 3502.820 & 9420.302 & 95 & 69.9 & 3.5 & 18.3 \\
\hline \multicolumn{8}{|c|}{ Lower Poteau River Watershed (HUC 1111010506) } \\
\hline 6 & Upper Sugar Loaf Creek & 3501.177 & 9425.285 & 7 & 88.6 & 1.6 & 1.3 \\
\hline \multicolumn{8}{|c|}{ Headwaters Poteau River Watershed (HUC 1111010501) } \\
\hline 7 & Lower Poteau River & 3455.666 & 9410.124 & 193 & 51.6 & 7.7 & 32 \\
\hline 8 & Headwaters Poteau River & 3453.769 & 9403.975 & 39 & 52.7 & 5.5 & 33.1 \\
\hline 9 & Ross Creek & 3451.647 & 9411.910 & 77 & 71.8 & 4.6 & 13.9 \\
\hline 10 & Upper Jones Creek & 3451.895 & 9412.835 & 73 & 84.8 & 2.7 & 2.2 \\
\hline \multicolumn{8}{|c|}{ Black Fork Watershed (HUC 1111010502) } \\
\hline 11 & Haw Creek & 3447.257 & 9430.924 & 62 & 90.3 & 1.8 & 1.1 \\
\hline 12 & Big Creek & 3442.970 & 9433.006 & 60 & 92.3 & 6.2 & 0 \\
\hline
\end{tabular}

\footnotetext{
a] Includes deciduous, evergreen, and mixed forests.

[b] Includes open space and low, medium, and high intensity development.

[c] Includes pasture, hay, and cultivated crops.
} 


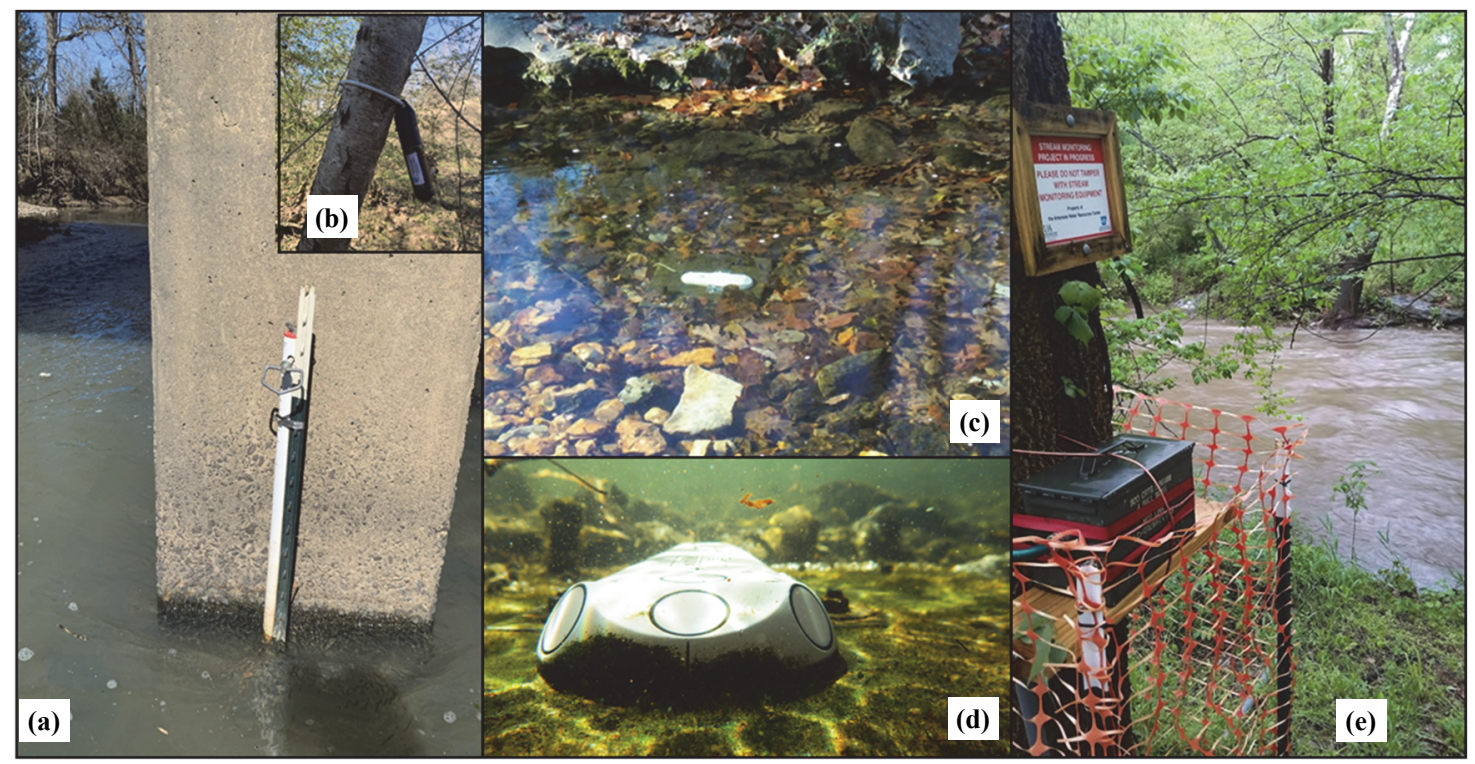

Figure 2. (a) Pressure transducer installed on the downstream side of a bridge pier, (b) atmospheric pressure transducer attached to a tree outside the floodplain, (c) SonTek-IQ instrument attached to a concrete base in the stream channel, (d) close up of SonTek-IQ instrument in the stream channel, and (e) battery container attached to a tree outside the floodplain.

- Lastly, Manning's equation was used for flow estimations above the range of the measured data (eq. 1):

$$
Q=\left(\frac{K}{n}\right) A R^{\frac{2}{3}} \sqrt{S}
$$

where

$Q=$ flow $\left(\mathrm{ft}^{3} \mathrm{~s}^{-1}\right)$

$K=$ unit conversion factor $\left(1.49 \mathrm{ft}^{1 / 3} \mathrm{~s}^{-1}\right)$

$n=$ surface roughness $\left(\mathrm{s} \mathrm{ft}^{-1 / 3}\right)$

$A=$ cross-sectional area of flow $\left(\mathrm{ft}^{2}\right)$

$R=$ hydraulic radius $(\mathrm{ft})$

$S=$ slope of channel $\left(\mathrm{ft} \mathrm{ft}^{-1}\right)$.

To estimate $A$ and $R$ in Manning's equation, an unsteady flow analysis was conducted in the Hydrologic Engineering Center's River Analysis System (HEC-RAS) (USACE, 2016). With inputs including the stream channel survey, LOESS rating curve data, and a stage hydrograph, the unsteady flow analysis computes the $A$ and the wetted perimeter (WP) for a range of user-defined depths. The $R$ at each depth is then computed as $A$ divided by the WP.

The best fit model for each rating curve was evaluated using the root mean square error (RMSE), where the lower the RMSE, the better the rating curve. To determine how well the observed data versus the simulated fit the 1:1 line, and to determine the relative magnitude of the residual variance, the Nash-Sutcliffe efficiency (NSE) was calculated for each model. An NSE of 1 indicates a perfect match of modeled data to observed data. The rating curve was then used to develop a record of continuous, instantaneous flow on a 15 min time interval.

\section{RESULTS}

\section{SELECTION OF SONTEK-IQ DATA}

Not all of the instantaneous flow measurements obtained with the SonTek-IQ instruments were necessary for rating curve development. In the initial analysis, peak flows and corresponding stages were selected from every high-flow event measured during SonTek-IQ deployment. Peak flows were paired with baseflow measurements and LOESS regressed against stage to develop a rating curve for each site. However, the data were sparse and left large gaps in the relationship (fig. 3a). In the second analysis, peak flows and $75 \%$ of peak flows (on the rising and falling limbs of the hydrograph) were paired with baseflow measurements and LOESS regressed (fig. 3b). However, again there was a gap in the data across the mid-range stage measurements. Therefore, peak flows, $75 \%$ of peak flows, and $50 \%$ of peak flows (on the rising and falling limbs of the hydrograph) were then paired with baseflow measurements and LOESS regressed (fig. 3c). With this data selection procedure, the range of flows better represented the range of stages, leaving fewer data gaps.

However, upon analysis of individual high-flow events, hysteresis was observed for many of the sites and events. In this study, hysteresis typically occurred as a delay in the peak stage following the peak flow (fig. 3d). Peak stages were typically delayed by an hour; therefore, to account for this delay, the final data selection method consisted of averaging the five values (on 15 min intervals) around the selected stages and flows. The final rating curves consisted of the averages around the peak flows, $75 \%$ of the peak flows, and $50 \%$ of the peak flows from the SonTek-IQ instruments, averages around the corresponding stages, and baseflow measurements (fig. 3e). The averaging also minimized noise in the data.

\section{Rating Curve Development}

For all sites, the range of measured stage data slightly exceeded the range of measured flow data. Therefore, flow must be projected when the stage is less than or greater than the range of stage data captured by flow measurements. For the sites where SonTek-IQ instruments were deployed, $89 \%$ 

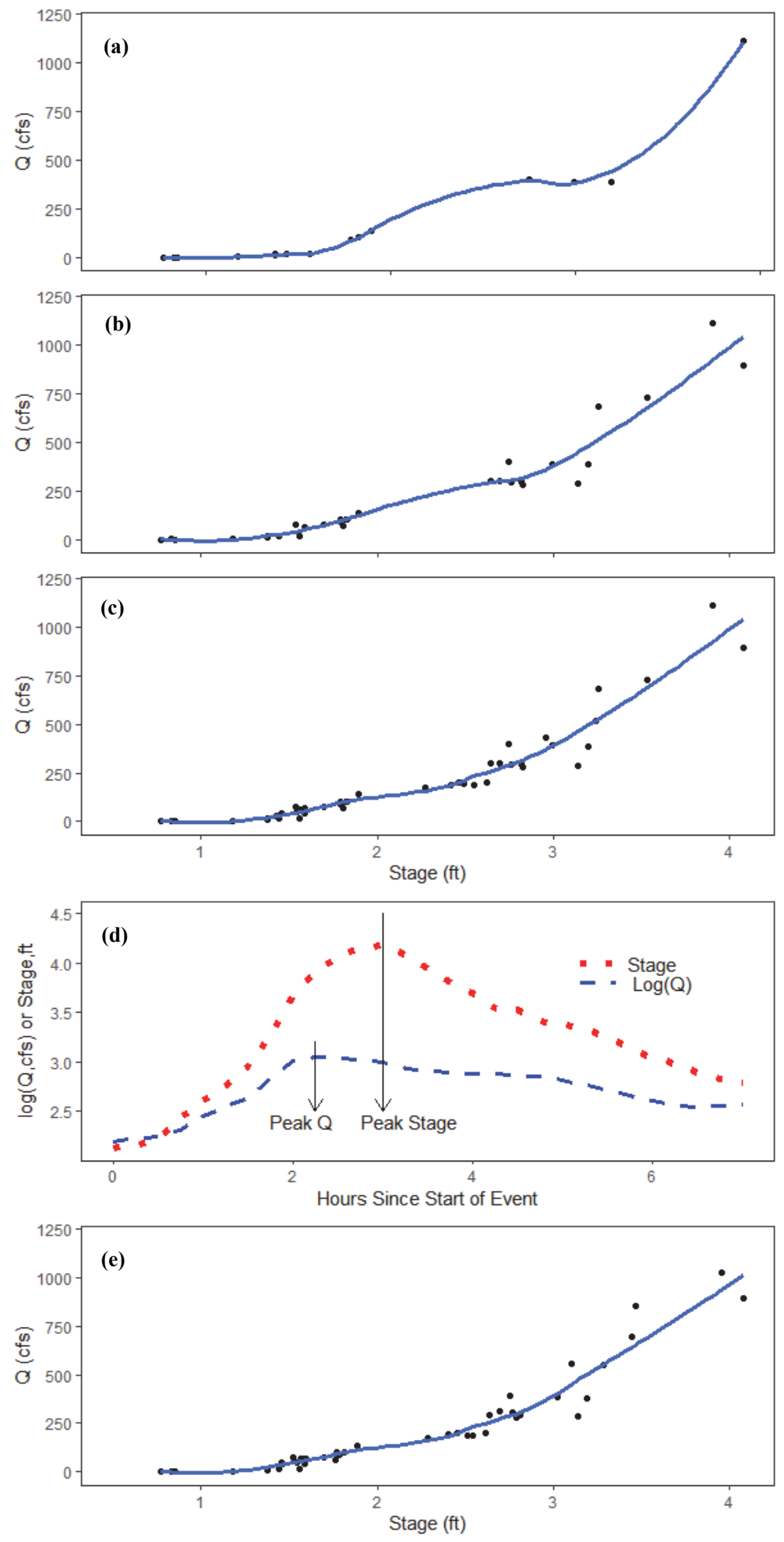

Figure 3. Combination of baseflow measurements and data selected from SonTek-IQ continuous measurements for rating curve development: (a) baseflow measurements and peak flows; (b) baseflow measurements, peak flows, and 75\% of peak flows; (c) baseflow measurements, peak flows, $75 \%$ of peak flows, and 50\% of peak flows; (d) hysteresis showing peak flow occurring approximately $1 \mathrm{~h}$ before peak stage; and (e) final selection of data from the SonTek-IQ instruments for rating curve development. Data consist of averages around the peak, $75 \%$ of peak, and $50 \%$ of peak stages and flows and baseflow measurements.

to $99 \%$ of the stage data were within the range of measured flow (fig. 4), estimated as the sum of flows below and above the range of measured data divided by the total sum of flows over the three-year period. Less than $1 \%$ of the stage data exceeded the maximum stage associated with a measured flow, and less than $11 \%$ of the stage data fell below the minimum stage associated with a measured flow. This is equivalent to less than six days of stage data exceeding the maximum measured flow and less than 115 days of stage data below the minimum measured flow throughout the three years of monitoring 

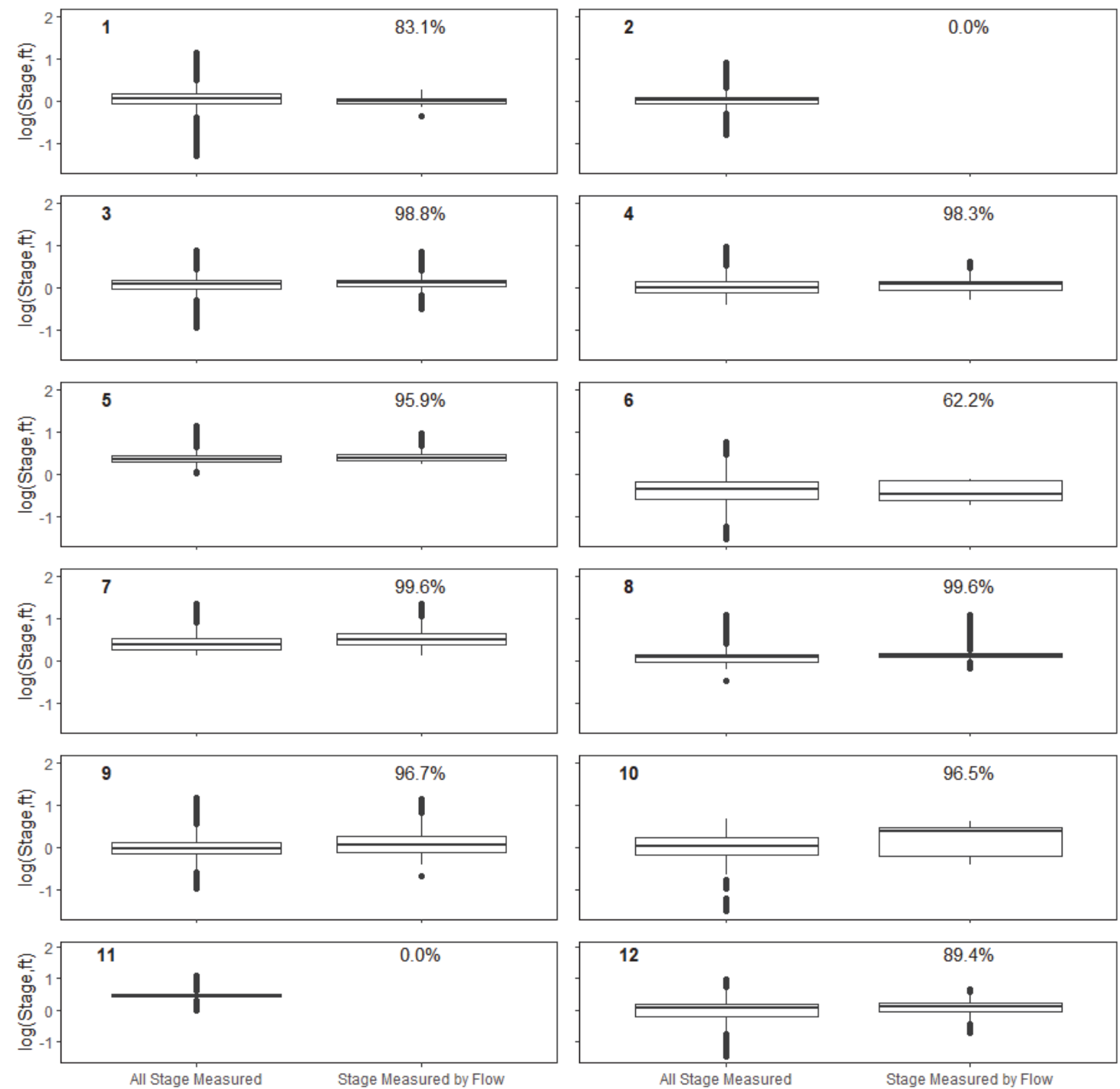

Figure 4. All measured stage data and stage data measured by flow across all sites. The numbers in the top left corners of the plots correspond to the site IDs in table 1. The values above "stage measured by flow" indicate the percentages of stage data measured by flow.

(table 2). Site 12 had the lowest proportion of stage data represented by flow $(89 \%)$, while all other sites with SonTek-IQ instruments had greater than $95 \%$ of stage data represented by flow. Sites 1 and 6 had discharge measured only during baseflow conditions, and sites 2 and 11 did not have baseflow measurements nor SonTek-IQ deployment.

Table 2. Percentage of stage measurements outside the range of flow and equivalent number of days with values greater than or less than flow over the three-year period (1,095 total days).

\begin{tabular}{ccccc}
\hline Site ID & $\begin{array}{c}\text { Percentage } \\
\text { Greater }\end{array}$ & $\begin{array}{c}\text { Days } \\
\text { Greater }\end{array}$ & $\begin{array}{c}\text { Percentage } \\
\text { Less }\end{array}$ & $\begin{array}{c}\text { Days } \\
\text { Less }\end{array}$ \\
\hline 1 & 12.5 & 1340.0 & 4.5 & 49.3 \\
2 & 100.0 & 453.0 & 0.0 & 0.0 \\
3 & 0.0 & 0.0 & 1.2 & 12.9 \\
4 & 0.5 & 5.5 & 1.2 & 12.9 \\
5 & 0.3 & 2.9 & 3.9 & 42.3 \\
6 & 17.8 & 194.0 & 20.0 & 213.0 \\
7 & 0.0 & 0.0 & 0.1 & 0.6 \\
8 & 0.0 & 0.0 & 0.4 & 4.6 \\
9 & 0.0 & 0.0 & 3.3 & 35.9 \\
10 & 0.2 & 2.4 & 3.3 & 35.8 \\
11 & 100.0 & 1095.0 & 0.0 & 0.0 \\
12 & 0.2 & 2.1 & 10.4 & 115.0 \\
\hline
\end{tabular}

To project flows below the range of the measured data, two-point regression was used between the minimum measured flow value and the origin. The slopes of the two-point regression ranged from 0.041 to $3.101 \mathrm{ft}^{2} \mathrm{~s}^{-1}$ across all sites (table 3). The two-point regression was used for less than $11 \%$ of the total flow at sites with SonTek-IQ deployment. The maximum percentage of total flow that had to be predicted on the lower end occurred at site $12(10.4 \%)$ but was less than $5 \%$ of the total flow for all other sites (table 2). Therefore, the projections below the range of the measured data likely had little influence on the estimated total monthly and/or annual flows.

Using the $A$ and $R$ values from HEC-RAS, an average $n$ was back-calculated using measured flow values and Manning's equation. The average $n$, as well as estimated WP and $R$ values from HEC-RAS, were used to project flow above the range of the measured data. Manning's $n$ ranged from 0.002 and 0.071 (table 3). Across all sites, it was necessary to use Manning's equation to predict high flows for less than $1 \%$ of flows. 
Table 3. Slopes of two-point regression for projecting below the range of measured data, average Manning's $n$ estimated using HEC-RAS and used to project flow above the range of measured data, and LOESS RMSE values for the range of measured data. NA indicates sites where SonTek-IQ instruments were not deployed.

\begin{tabular}{cccc}
\hline Site ID & $\begin{array}{c}\text { Slope of } \\
\text { Two-Point } \\
\text { Regression }\end{array}$ & $\begin{array}{c}\text { Average } \\
\text { Manning's } n\end{array}$ & $\begin{array}{c}\text { LOESS } \\
\text { RMSE }\end{array}$ \\
\hline 1 & NA & NA & NA \\
2 & NA & NA & NA \\
3 & 0.041 & 0.05 & 183 \\
4 & 0.953 & 0.022 & 52.2 \\
5 & 0.211 & 0.031 & 3.63 \\
6 & NA & NA & NA \\
7 & 0.306 & 0.071 & 210 \\
8 & 0.080 & 0.002 & 153 \\
9 & 2.371 & 0.023 & 379 \\
10 & 0.109 & 0.036 & 25.8 \\
11 & NA & NA & NA \\
12 & 3.101 & 0.025 & 189 \\
\hline
\end{tabular}

For the range of measured stage and flow data, LOESS regression was applied with a sampling proportion of 0.5 . The RMSE values from LOESS regression ranged from 3.63 to 379 across all sites (table 3). While normal distributions are not required for LOESS regression, the large amount of spread in the data at site 5 justified a square root data transformation (fig. 5). A square root transformation was chosen due to its ability to handle zero values. Final rating curves for each site were developed by combining the two-point regression, LOESS regression, and Manning's equation data (fig. 5).

The performance of the rating curve models was evaluated by visualizing the predicted flows over time in conjunction with the measured flows (fig. 6). Additionally, the NashSutcliffe efficiencies for all sites ranged between 0.87 and 0.98 (fig. 5). Overall, the model-predicted flows well represented the measured flows.

\section{DisCUSSION}

Continuous discharge measurements are imperative for water resources management, but currently these data are limited or nonexistent for many small-scale streams. Over the last two decades, efforts to predict flow in ungauged watersheds have been an active area of research (Hauet et al., 2008; Royem et al., 2012; Atieh et al., 2017; Tegegne and $\mathrm{Kim}, 2020$ ), with methods often involving hydrologic models (Gitau and Chaubey, 2010; Tegegne and Kim, 2020), instantaneous flow measurements and rating curves (Harmel et al., 2006), or regression relationships between watershed/stream characteristics and flow (Chen and Chiu, 2004; Gianfagna et al., 2015). However, these efforts can be data intensive (Razavi and Coulibaly, 2013), unreliable (e.g., with indirect measurements), or logistically unfeasible across numerous, remote sites. The method proposed in this study provides an opportunity to fill this data gap by collecting continuous records of flow across multiple, remote, small-scale watersheds.

A variety of methods have been used to successfully collect flow measurements for use in rating curve development. The most common flow measurement methods include direct measurement (e.g., timed volume), velocity-area methods (e.g., float method, dilution gauging, trajectory method, current meters, acoustic Doppler current profilers, and electromagnetic method), formed constriction methods (e.g., weirs and flumes), and non-contact methods (e.g., remote sensing and particle image velocimetry) (Gravelle, 2015; Dobriyal et al., 2017). Direct and formed constriction methods are impractical across numerous sites, and these methods can be expensive and difficult to operate. Non-contact methods are costly, do not measure streamflow directly, and require extensive ground-checking and validation.

While acoustic Doppler instruments (e.g., SonTek-IQ) are costly, they are highly accurate, and the proposed method allows direct installation of the instrument in the stream, removing the need for technicians to measure instantaneous flow during dangerous conditions. Additionally, SonTek-IQ instruments can be rotated among numerous sites between flood events, so an instrument does not have to be purchased for every monitoring site of interest. The proposed method also removes the logistical hindrance of trying to measure peak flows at numerous, remote sites, when peak flows are often short-lived in small-scale streams.

Nonlinear regression analyses are a common practice for rating curve development (Westphal et al., 1999; Reitan and Petersen-Øverleir, 2008; Fenton, 2018; Tamagnone et al., 2019), but few studies have applied locally weighted regressions such as LOESS. The benefit of locally weighted regression is the ability to fit the curve-linear shape of measured stage and discharge data, as well as compute uncertainty bounds around the predictions. Across 500 streams in the U.K., nonparametric LOWESS regression was used to fit rating curves and estimate discharge uncertainty, which resulted in a robust and versatile framework for hydrologic analyses (Coxon et al., 2015). Additionally, for a low-gradient subcatchment in Louisiana, artificial neural networks and local nonparametric regression (LOESS) were compared for modeling rating curves. While the artificial neural networks performed slightly better than LOESS, both techniques agreed well with the observed discharge measurements (Habib and Meselhe, 2006).

Extension of rating curves outside the range of measured data is often necessary when developing continuous records of flow. When SonTek-IQ instruments were deployed this study, at least $89 \%$ of all stage measurements were captured by flow data, meaning that flow measurements had to be predicted outside the range of the measured data less than $11 \%$ of the time. Extension of rating curves is often done using the existing model, developing a new model using watershed/stream characteristics, or using Manning's equation (Sivapragasam and Muttil, 2005). Manning's equation is commonly used to predict flow in ungauged streams, and it was chosen for this study because hydrological information can be estimated from existing stage-discharge relationships. While rating curves and extrapolation with Manning's equation have often been adapted (Leonard et al., 2000; Leon et al., 2006; Pan et al., 2016), the need for extrapolation in the proposed method could be reduced with continued or extended deployments of SonTek-IQ instruments.

The downfall of many typical rating curve techniques is their inability to accurately represent hysteresis in the stagedischarge relationships. As occurred in this study, hysteresis 

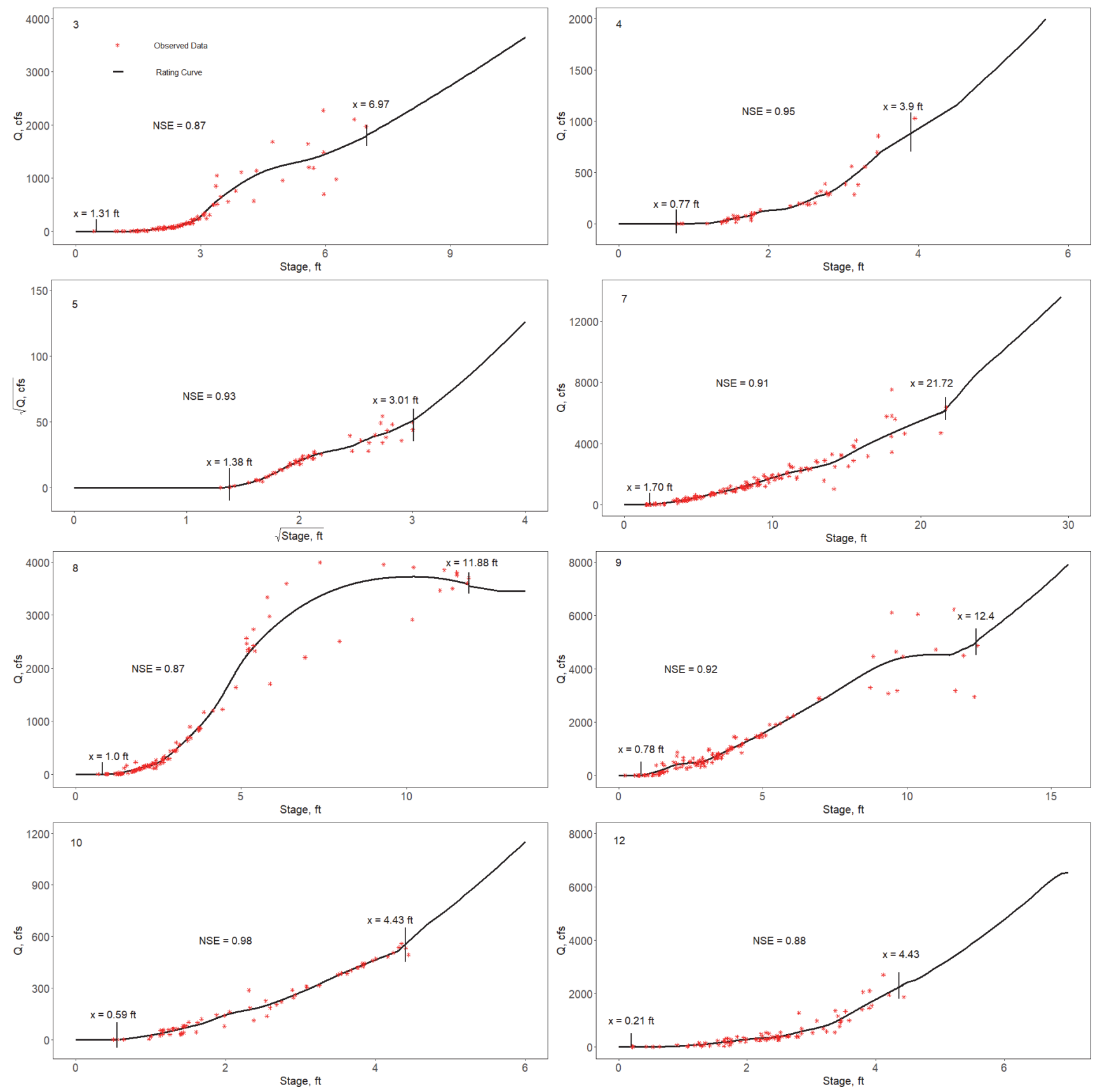

Figure 5. Final rating curves for all sites with measured flow data. The numbers in the upper left corners of each plot correspond to the site IDs in table 1. Models were developed using LOESS regression across the range of measured flow data, two-point regression to project flow less than the minimum measured value, and Manning's equation to project flow greater than the maximum measured value.

typically appears as higher flows at a given stage on the rising limb of a hydrograph compared to the same stage on the falling limb, creating a loop in the rating curve. This can be observed for site 8 in figure 5, where many data points from the largest storm event (i.e., measurements above $6 \mathrm{ft}$ stage) were included to increase the sample size on the higher end. Historically, two methods have been used to incorporate hysteresis into rating curves: (1) separate rating curves for the rising and falling limbs of hydrographs, and (2) the Jones equation (Jones, 1916). The first method, i.e., developing separate rating curves, often produces separation in the discharge hydrograph (Tawfik et al., 1997), so the Jones equation has been widely applied to adjust a single rating cure for unsteady flow (Perumal et al., 2004; Petersen-Øverleir, 2006). However, the Jones equation requires accurate identification of hydraulic parameters such as channel resistance, bed slope, channel length, and friction law, and it has shown significant error near peak flow where large hysteresis occurs (Perumal and Raju, 1999).

While the selection of data across the hydrograph and the use of LOESS regression in this study may not adequately capture hysteresis, it provides a method to essentially average the flows on the higher ends of the measured stage. Additionally, the purpose of these data is to estimate daily flows for use in constituent load estimations and model calibration and validation (on a daily scale or larger). Therefore, 

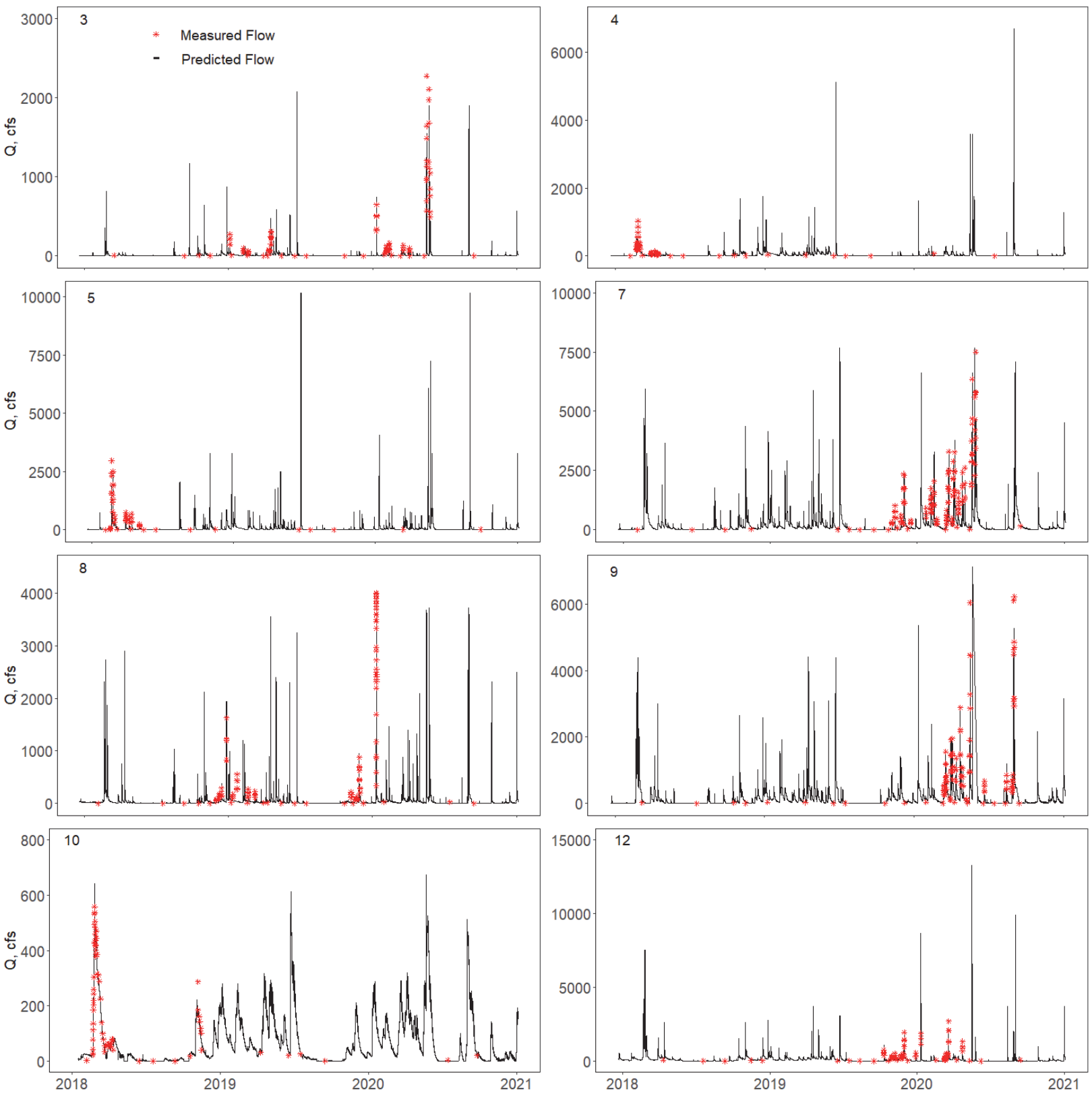

Figure 6. Manual and SonTek-IQ measured flows with predicted flows from rating curves. The numbers in the upper left corners of each plot correspond to the site IDs in table 1.

averaging of the instantaneous measurements seems acceptable. However, if the data are to be used on a finer time scale (i.e., hourly, $15 \mathrm{~min}$, etc.), then a different approach to the rating curve models may be necessary to accurately represent hysteresis.

The purchase and installation cost of a typical USGS monitoring gauge is about $\$ 25,000$, with a minimum operating cost of about $\$ 15,000$ per year (Michael Norris, USGS, personal communication, 11 June 2018). Therefore, to monitor eight streams (i.e., the number of streams in which SonTek-IQ instruments were installed in this study), the total cost for three years would be at least $\$ 560,000$. However, using the method developed in this study, a $\$ 9,000$ SonTekIQ instrument is not required for each site. The cost of additional equipment and installation, besides the SonTek-IQ, is about $\$ 1,200$ per site. Therefore, assuming the purchase of three SonTek-IQ instruments, eight sites would cost about $\$ 36,000$ for equipment purchase and installation. We also estimated operating and maintenance costs to be about $\$ 110,000$ for three years, assuming the salary and benefits for a typical lab technician working half-time to maintain this project, resulting in a total project cost of $\$ 146,000$. This is about $25 \%$ of the cost required if USGS gauge systems were used, and may even be less because minimum estimations were used for the USGS costs. Additionally, adding more sites to this monitoring method would only require additional HOBO pressure transducers and equipment for the HOBO and SonTek-IQ installations ( $\$ 1,200$ per site), because the SonTek-IQ instruments can be rotated among sites. Therefore, the proposed method appears to be a cost-efficient alternative for continuous flow measurement at numerous, small-scale streams. 
Some limitations were recognized while implementing this monitoring method across the UPRW. No flow measurements were collected at sites 2 and 11 because the streams were too deep to wade for baseflow discharge measurements and SonTek-IQ installation. Additionally, the selected sites were limited to locations near bridge crossings to collect water samples. Thus, monitoring sites must be investigated thoroughly before selection to ensure that the streams are at an appropriate depth under baseflow conditions for equipment installation. Because this monitoring method seeks to fill the data gap for small-scale streams, this should be feasible for most streams of interest.

Equipment malfunction and loss is always a risk in stream monitoring efforts, especially during flood events. At site 12, a SonTek-IQ instrument was lost during a storm event in January 2020 (fig. 6, where maximum flow occurred). The streambed at site 12 consists mostly of cobbles and boulders, and a large boulder likely shattered the concrete base where the SonTek-IQ was installed, allowing pieces to break free and the SonTek-IQ to be washed away during the flood. Therefore, a different installation method for SonTek-IQ instruments should be explored for sites with streambeds similar to site 12 . Concrete reinforced with wire or rebar may provide a stronger base under these conditions.

At site 1, a SonTek-IQ instrument was installed for only a short time before loose shale sediment covered the instrument during each high-flow event. This resulted in limited flow measurements from the SonTek-IQ, and a rating curve was not produced for this site. Therefore, streams with loose substrate similar to site 1 may not provide optimal conditions for monitoring with the proposed method. However, the deployment time was limited at this site, and a longer deployment could have provided more usable data for rating curve development.

Long-term monitoring data are essential for understanding changes in natural environments, including trends, cycles, and identification of rare events (Burt et al., 2014). However, due to fluctuations in the streambeds and crosssectional areas of streams over time, rating curve relationships can also change over time (Tomkins, 2014). Using the proposed method, SonTek-IQ instruments would likely need to be redeployed every few years to update the rating curve relationships for long-term monitoring. Stage measurements can easily be continued for extended time periods, and SonTek-IQ instruments can remain in streams for simple removal and reinstallation when necessary.

Because continuous records of flow are typically limited or non-existent at the small-stream scale, constituent loads and trends in flow-adjusted nutrients and sediments are also limited at this scale. Water quality sampling can easily be integrated into the proposed method by collecting water samples across the range of flows and analyzing for parameters of interest. This would provide data for calibration and validation of watershed models, help to identify small-scale pollution sources for watershed management, and allow analyses of land use impacts on water quality at much finer resolutions.

\section{CONCLUSIONS}

Simple, inexpensive pressure transducers in conjunction with SonTek-IQ acoustic Doppler instruments can be used to monitor streamflow and develop rating curves across numerous, small streams. The proposed method provides continuous records of flow across remote, small-scale watersheds, where data are typically limited or nonexistent. The method can be easily integrated into existing monitoring projects, and in conjunction with water quality data, can be used to estimate nutrient loads. The method can provide data for calibration and validation of watershed models, help to identify small-scale pollution sources for watershed management, and allow analyses of land use impacts on water quality at much finer resolutions. Monitoring data at this scale provide more opportunities to address nonpoint pollution sources and improve surface water quality.

\section{ACKNOWLEDGEMENTS}

This work was supported, at least in part, by the USDA National Institute of Food and Agriculture (Hatch Project 2660), the Arkansas Water Resources Center through the USGS Water Resources Research Institute 104B Program, the UA Division of Agriculture, the Arkansas Natural Resource Commission (Project 17-300), and Environmental Protection Agency Section 319(h). Any opinions, findings, conclusions, or recommendations expressed in this publication are those of the authors and do not necessarily reflect the view of the USDA or the U.S. Department of the Interior.

\section{REFERENCES}

ADEQ. (2018). Arkansas's final impaired waterbodies: 303(d) list. Little Rock, AR: Arkansas Department of Environmental Quality.

ANRC. (2018). Nonpoint-source pollution management plan. Little Rock, AR: Arkansas Natural Resource Commission.

Atieh, M., Taylor, G., M.A. Sattar, A., \& Gharabaghi, B. (2017). Prediction of flow duration curves for ungauged basins. $J$. Hydrol., 545, 383-394. https://doi.org/10.1016/j.jhydrol.2016.12.048

Aylward, B., Bandyopadhyay, J., Belausteguigotia, J.-C., Börkey, P., Cassar, A., Meadors, L., ... Rijsberman, F. (2005). Chapter 7: Freshwater ecosystem services. In Ecosystems and human wellbeing: Volume 3. Policy responses (pp. 213-255). Washington, DC: Island Press.

Burt, T. P., Howden, N. J., \& Worrall, F. (2014). On the importance of very long-term water quality records. WIREs Water, 1(1), 4148. https://doi.org/10.1002/wat2.1001

Chen, X., Hao, Z., Devineni, N., \& Lall, U. (2014). Climate information based streamflow and rainfall forecasts for Huai River basin using hierarchical Bayesian modeling. Hydrol. Earth Syst. Sci., 18(4), 1539-1548. https://doi.org/10.5194/hess-181539-2014

Chen, Y.-C., \& Chiu, C.-L. (2004). A fast method of flood discharge estimation. Hydrol. Proc., 18(9), 1671-1684. https://doi.org/10.1002/hyp.1476

Cohn, T. A., Delong, L. L., Gilroy, E. J., Hirsch, R. M., \& Wells, D. K. (1989). Estimating constituent loads. Water Resour. Res., 25(5), 937-942. https://doi.org/10.1029/WR025i005p00937

Coxon, G., Freer, J., Westerberg, I. K., Wagener, T., Woods, R., \& Smith, P. J. (2015). A novel framework for discharge uncertainty quantification applied to 500 U.K. gauging stations. 
Water Resour. Res., 51(7), 5531-5546. https://doi.org/10.1002/2014WR016532

Dai, A., \& Trenberth, K. E. (2002). Estimates of freshwater discharge from continents: Latitudinal and seasonal variations. $J$. Hydrometeorol., 3(6), 660-687. https://doi.org/10.1175/15257541(2002)003<0660: eofdfc $>2.0 . c 0 ; 2$

Dobriyal, P., Badola, R., Tuboi, C., \& Hussain, S. A. (2017). A review of methods for monitoring streamflow for sustainable water resource management. Appl. Water Sci., 7(6), 2617-2628. https://doi.org/10.1007/s13201-016-0488-y

Dudgeon, D., Arthington, A. H., Gessner, M. O., Kawabata, Z.-I., Knowler, D. J., Lévêque, C., ... Sullivan, C. A. (2006). Freshwater biodiversity: Importance, threats, status, and conservation challenges. Biol. Rev., 81(2), 163-182. https://doi.org/10.1017/S1464793105006950

Erwin, M. L., \& Hamilton, P. A. (2005). Monitoring our rivers and streams. Reston, VA: U.S. Geological Survey.

Fenton, J. D. (2018). On the generation of stream rating curves. $J$. Hydrol., 564, 748-757. https://doi.org/10.1016/j.jhydrol.2018.07.025

Gianfagna, C. C., Johnson, C. E., Chandler, D. G., \& Hofmann, C. (2015). Watershed area ratio accurately predicts daily streamflow in nested catchments in the Catskills, New York. $J$. Hydrol. Reg. Stud., 4, 583-594. https://doi.org/10.1016/j.ejrh.2015.09.002

Gitau, M. W., \& Chaubey, I. (2010). Regionalization of SWAT model parameters for use in ungauged watersheds. Water, 2(4), 849-871. https://doi.org/10.3390/w2040849

Gravelle, R. (2015). Discharge estimation: Techniques and equipment. Geomorphological techniques, Chapter 3, Section 3.5. London, UK: British Society for Geomorphology. Retrieved from

http://geomorphology.org.uk/sites/default/files/geom_tech_chapt ers/3.3.5 DischargeEstimation.pdf

Habib, E. H., \& Meselhe, E. A. (2006). Stage-discharge relations for low-gradient tidal streams using data-driven models. $J$. Hydraul. Eng., 132(5), 482-492. https://doi.org/10.1061/(ASCE)0733-9429(2006)132:5(482)

Haritashya, U. K., Singh, P., Kumar, N., \& Singh, Y. (2006). Hydrological importance of an unusual hazard in a mountainous basin: Flood and landslide. Hydrol. Proc., 20(14), 3147-3154. https://doi.org/10.1002/hyp.6397

Harmel, R. D., King, K. W., Haggard, B. E., Wren, D. G., \& Sheridan, J. M. (2006). Practical guidance for discharge and water quality data collection on small watersheds. Trans. ASABE, 49(4), 937-948. https://doi.org/10.13031/2013.21745

Hauet, A., Creutin, J.-D., \& Belleudy, P. (2008). Sensitivity study of large-scale particle image velocimetry measurement of river discharge using numerical simulation. J. Hydrol., 349(1), 178190. https://doi.org/10.1016/j.jhydrol.2007.10.062

Helsel, D. R., \& Hirsch, R. M. (1991). Statistical methods in water resources. Reston, VA: U.S. Geological Survey.

Hirsch, R. M., Slack, J. R., \& Smith, R. A. (1982). Techniques of trend analysis for monthly water quality data. Water Resour. Res., 18(1), 107-121. https://doi.org/10.1029/WR018i001p00107

Jiménez Cisneros, B. E., Oki, T., Arnell, N. W., Benito, G., Cogley, J. G., Doll, P., \& Mwakalila, S. S. (2014). Chapter 3: Freshwater resources. In AR5 Climate Change 2014: Impacts, adaption, and vulnerability: Part A. Global and sectoral aspects (pp 229-269) Cambridge, UK: Cambridge University Press.

Jones, B. E. (1916). A method of correcting river discharge for a changing stage. USGS Water Supply Paper 375-E. Reston, VA: U.S. Geological Survey.

Leon, J. G., Calmant, S., Seyler, F., Bonnet, M. P., Cauhope, M., Frappart, F., ... Fraizy, P. (2006). Rating curves and estimation of average water depth at the upper Negro River based on satellite altimeter data and modeled discharges. J. Hydrol., 328(3), 481-496. https://doi.org/10.1016/j.jhydrol.2005.12.006

Leonard, J., Mietton, M., Najib, H., \& Gourbesville, P. (2000). Rating curve modeling with Manning's equation to manage instability and improve extrapolation. Hydrol. Sci. J., 45(5), 739750. https://doi.org/10.1080/02626660009492374

Martin, D. M., Labadie, J. W., \& Poff, N. L. (2015). Incorporating social preferences into the ecological limits of hydrologic alteration (ELOHA): A case study in the Yampa-White River basin, Colorado. Freshwater Biol., 60(9), 1890-1900. https://doi.org/10.1111/fwb.12619

Migliaccio, K. W., Castro, J., \& Haggard, B. E. (2010). Water quality statistical analysis. In Y. Li \& K. W. Migliaccio (Eds.), Water quality concepts, sampling, and analyses (pp. 241-274). Boca Raton, FL: CRC Press. https://doi.org/10.1201/b10157

Onset. (2018). HOBO U20 water level logger (U20-001-0x and U20-001-0x-Ti) manual. Bourne, MA: Onset Computer. Retrieved from www.onsetcomp.com

Pai, N., Saraswat, D., \& Daniels, M. (2011). Identifying priority subwatersheds in the Illinois River Drainage Area in Arkansas watershed using a distributed modeling approach. Trans. ASABE, 54(6), 2181-2196. https://doi.org/10.13031/2013.40657

Pan, F., Wang, C., \& Xi, X. (2016). Constructing river stagedischarge rating curves using remotely sensed river crosssectional inundation areas and river bathymetry. J. Hydrol., 540, 670-687. https://doi.org/10.1016/j.jhydrol.2016.06.024

Perumal, M., \& Raju, K. G. (1999). Approximate convectiondiffusion equations. J. Hydrol. Eng., 4(2), 160-164. https://doi.org/10.1061/(ASCE)1084-0699(1999)4:2(160)

Perumal, M., Shrestha, K. B., \& Chaube, U. C. (2004). Reproduction of hysteresis in rating curves. J. Hydraul. Eng., 130(9), 870-878. https://doi.org/10.1061/(ASCE)07339429(2004)130:9(870)

Petersen-Øverleir, A. (2006). Modeling stage-discharge relationships affected by hysteresis using the Jones formula and nonlinear regression. Hydrol. Sci. J., 51(3), 365-388. https://doi.org/10.1623/hysj.51.3.365

Peterson, T. C., Heim, R. R., Hirsch, R., Kaiser, D. P., Brooks, H., Diffenbaugh, N. S., ... Wuebbles, D. (2013). Monitoring and understanding changes in heat waves, cold waves, floods, and droughts in the United States: State of knowledge. Bull. American Meteorol. Soc., 94(6), 821-834. https://doi.org/10.1175/bams-d-12-00066.1

Poff, N. L., Richter, B. D., Arthington, A. H., Bunn, S. E., Naiman, R. J., Kendy, E., ... Warner, A. (2010). The ecological limits of hydrologic alteration (ELOHA): A new framework for developing regional environmental flow standards. Freshwater Biol., 55(1), 147-170. https://doi.org/10.1111/j.13652427.2009.02204.x

Razavi, T., \& Coulibaly, P. (2013). Streamflow prediction in ungauged basins: Review of regionalization methods. J. Hydrol. Eng., 18(8), 958-975. https://doi.org/10.1061/(ASCE)HE.19435584.0000690

Reitan, T., \& Petersen-Øverleir, A. (2008). Bayesian power-law regression with a location parameter, with applications for construction of discharge rating curves. Stochastic Environ. Res. Risk Assess., 22(3), 351-365. https://doi.org/10.1007/s00477007-0119-0

Royem, A. A., Mui, C. K., Fuka, D. R., \& Walter, M. T. (2012). Technical note: Proposing a low-tech, affordable, accurate stream stage monitoring system. Trans. ASABE, 55(6), 2237 2242. https://doi.org/10.13031/2013.42512

Sala, O. E., Chapin, F. S., Armesto, J. J., Berlow, E., Bloomfield, J., Dirzo, R., ... Wall, D. H. (2000). Global biodiversity scenarios 
for the year 2100. Science, 287(5459), 1770-1774.

https://doi.org/10.1126/science.287.5459.1770

Silberstein, R. P. (2006). Hydrological models are so good, do we still need data? Environ. Model. Software, 21(9), 1340-1352. https://doi.org/10.1016/j.envsoft.2005.04.019

Sivapragasam, C., \& Muttil, N. (2005). Discharge rating curve extension: A new approach. Water Resour. Mgmt., 19(5), 505520. https://doi.org/10.1007/s11269-005-6811-2

Solans, M. A., \& Garcia de Jalón, D. (2016). Basic tools for setting environmental flows at the regional scale: Application of the ELOHA framework in a Mediterranean river basin. Ecohydrology, 9(8), 1517-1538. https://doi.org/10.1002/eco.1745

SonTek-IQ. (2017). SonTek-IQ Series user's manual. San Diego, CA: SonTek/Xylem. Retrieved from https://www.sontek.com/sontek-iq-series

Stein, E. D., Sengupta, A., Mazor, R. D., McCune, K., Bledsoe, B. P., \& Adams, S. (2017). Application of regional flow-ecology relationships to inform watershed management decisions: Application of the ELOHA framework in the San Diego River watershed, California, USA. Ecohydrology, 10(7), e1869. https://doi.org/10.1002/eco.1869

Tamagnone, P., Massazza, G., Pezzoli, A., \& Rosso, M. (2019). Hydrology of the Sirba River: Updating and analysis of discharge time series. Water, 11(1), article 156. https://doi.org/10.3390/w11010156

Tawfik, B. M., Ibrahim, A., \& Fahmy, H. (1997). Hysteresis sensitive neural network for modeling rating curves. J. Comput. Civil Eng., 11(3), 206-211. https://doi.org/10.1061/(ASCE)0887-3801(1997)11:3(206

Tegegne, G., \& Kim, Y.-O. (2020). Strategies to enhance the reliability of flow quantile prediction in the gauged and ungauged basins. River Res. Appl., 36(5), 724-734. https://doi.org/10.1002/rra.3603

Tomkins, K. M. (2014). Uncertainty in streamflow rating curves: Methods, controls, and consequences. Hydrol. Proc., 28(3), 464481. https://doi.org/10.1002/hyp.9567
Tripathi, M. P., Panda, R. K., \& Raghuwanshi, N. S. (2003). Identification and prioritization of critical subwatersheds for soil conservation management using the SWAT model. Biosyst. Eng., 85(3), 365-379. https://doi.org/10.1016/S15375110(03)00066-7

Turnipseed, D. P., \& Sauer, V. B. (2010). Discharge measurements at gaging stations. USGS techniques and methods 3-A8. Reston, VA: U.S. Geological Survey. https://doi.org/10.3133/tm3A8

USACE. (2016). HEC-RAS river analysis system user's manual. Davis, CA: U.S. Army Corps of Engineers.

USDA. (2017). Quick Stats database. Washington, DC: USDA National Agricultural Statistics Service.

USEPA. (2006). TMDLs for phosphorus, copper, and zinc for the Poteau River near Waldron, AR. Dallas, TX: U.S. Environmental Protection Agency.

USGS. (2001). NLCD 2001 land cover. Reston, VA: U.S. Geological Survey. Retrieved from https://www.mrlc.gov/data/nlcd-2001-land-cover-conus

USGS. (2016). National land cover database. Reston, VA: U.S. Geological Survey. Retrieved from https://www.mrlc.gov/data?f $\% 5 \mathrm{~B} 0 \% 5 \mathrm{D}=$ category $\% 3 \mathrm{Aland}$ cover\& $\% 5 \mathrm{~B} 1 \% 5 \mathrm{D}=$ year $\% 3 \mathrm{~A} 2016$

Welde, K. (2016). Identification and prioritization of subwatersheds for land and water management in Tekeze Dam watershed, northern Ethiopia. Intl. Soil Water Conserv. Res., 4(1), 30-38. https://doi.org/10.1016/j.iswcr.2016.02.006

Westphal, J. A., Thompson, D. B., Stevens, G. T., \& Strauser, C. N. (1999). Stage-discharge relations on the middle Mississippi River. J. Water Resour. Plan. Mgmt., 125(1), 48-53. https://doi.org/10.1061/(ASCE)0733-9496(1999)125:1(48)

Zhang, Z., Balay, J. W., Bertoldi, K. M., \& MaCoy, P. O. (2016). Assessment of water capacity and availability from unregulated stream flows based on ecological limits of hydrologic alteration (ELOHA) environmental flow standards. River Res. Appl., 32(7), 1469-1480. https://doi.org/10.1002/rra.2979 